10: PERSPECTIVES IN CRITICISM 


\section{PERSPECTIVES IN CRITICISM}

1: Elements of Critical Theory

2: The Disinherited of Art

3: Stream of Consciousness in the Modern Novel

4: The Poet in the Poem

5: Arthurian Triptych

6: The Brazilian Othello of Machado de Assis

7: The World of Jean Anouilh

8: A New Approach to Joyce

9: The Idea of Coleridge's Criticism

10: Introduction to the Psychoanalysis of Mallarmé 


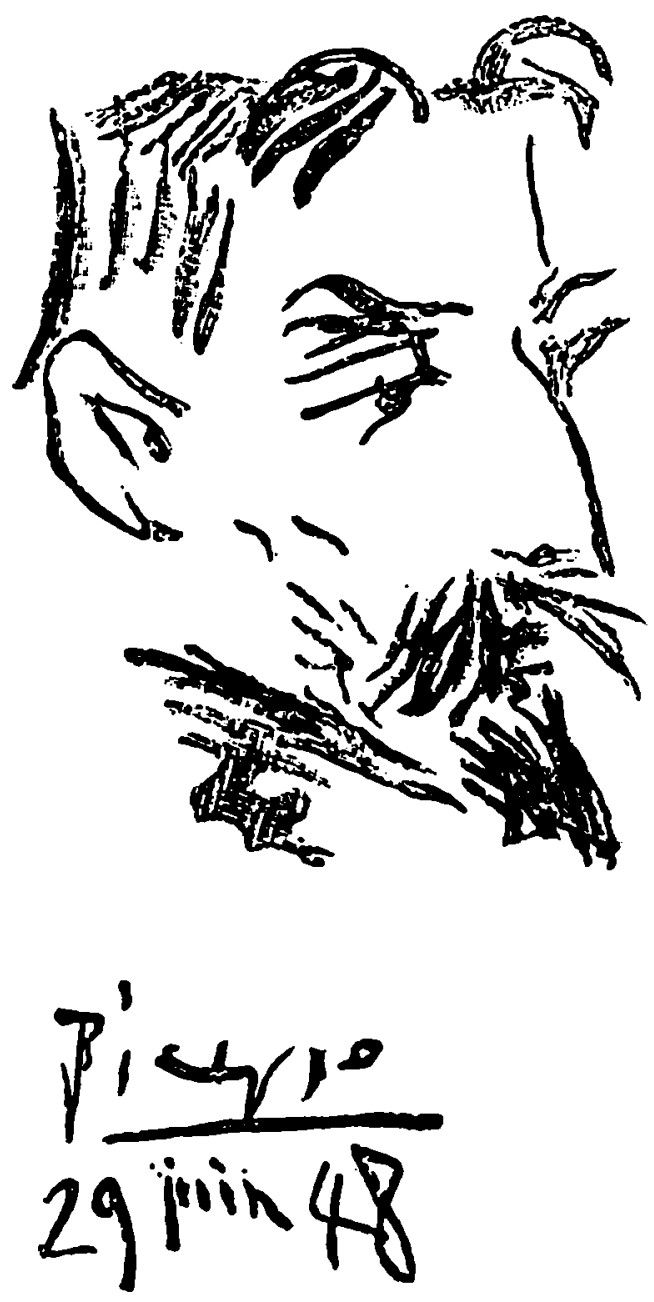

Portrait of Mallarmé by Pablo Picasso

Engraved by Angladon. From the Flandreysy-Espérandieu Collection, Archives of the Palais du Roure, Avignon. 


\section{0:}

Charles Mauron

Translated from the French by

Archibald Henderson, Jr., and Will L. McLendon

\section{Introduction to the Psychoanalysis of Mallarmé}

UNIVERSITY OF CALIFORNIA PRESS

Berkeley and Los Angeles 1963 
(c) 1963 by The Regents of the University of California

University of California Press Berkeley and Los Angeles, Califormia

Cambridge University Press

London, England

L'Introduction à la psychanalyse de Mallarmé, FIRST PUBLISHED IN NEUCHÂTEL, SWITZERLAND, BY LES EDITIONS DE LA BACONNIÈRE À BOUDRY, 1950

PUBLISHED WITH THE ASSISTANCE OF A GRANT FROM THE UNIVERSITY OF HOUSTON

LIBRARY OF CONGRESS CATALOG CARD NUMBER: 63-8918

Printed in the United States of America

Designed by Ward Ritchie 